ljtihad: Jurnal Wacana Hukum Islam dan Kemanusiaan

Vol. 20, No. 1 (2020), pp. 41-60, doi : 10.18326/ijtihad.v20i1.41-60

\title{
The developmental policy of halal product guarantee in the paradigm of maqāșid shariah in Indonesia
}

\author{
Agus Waluyo \\ Institut Agama Islam Negeri (LAIN) Salatiga \\ E-Mail:aguswaluyo@iainsalatiga.ac.id \\ DOI: $10.18326 /$ ijtihad.v20i1.41-60
}

The guarantee of halal products that meet the quality, hygiene, health and safety standards has become a primary need for every person to protect religion and soul. This study aims to elaborate government policies related to regulations in supporting the development of halal industry and its barriers to implement halal product guarantee. In addition, this study also tries to reveal halal industrial development strategies. This article is qualitative research using library approach. The research findings show that to guarantee halal product in a systematic and comprehensive way for Indonesian society, the government has issued JPH Law which contains maqäsid shariah values. Besides, it is found difficulties in the process of obtaining halal certification faced by the producers. This study implies that it still needs rules from the government to support the implementation of JPH Law so that it can encourage the development of halal industry, which finally can establish Indonesia as the epicentre of the world sharia economy.

Keywords: halal product guarantee; halal industry; maqäsid shariah; Islamic economics

\section{Introduction}

Halal is a universal indicator for measuring product and lifestyle (Gillani et al, 2016). As the world's Muslim population grows, the demand for halal commodities continues to increase. Halal lifestyle has developed so fast in some countries, even in countries with minority Muslim populations. Halal lifestyle develops along with human needs which relate not only to food, but also to various broader sectors of life such as clothing, tourism, hotel, housing, 
ljtihad: Jurnal Wacana Hukum Islam dan Kemanusiaan, Volume 20, No. 1, Juni 2020: 41-60

and cosmetic (Darojatun, 2018). The rapid development in these sectors goes in line with the development of global Islamic finance. The diversity of consumption of halal products shows an increase in interest in the halal lifestyle.

Recently, the Indonesian Sharia Economic Festival (ISEF) 2019 was held at the Jakarta Convention Center on November 12-16, 2019 with the theme "Sharia Economy for Stronger and Sustainable Growth". The government initiated this event through Bank Indonesia in collaboration with the National Committee of Sharia Finance (NCSF), the Financial Services Authority (OJK), and related institutions. The international event which involved prominent figures, experts, researchers, students, and UMKM actors was a media to promote halal lifestyle and sharia economy. The recommendations of the event are the creation of the Indonesia Integrated Halal Ecosystem (IIHE), which consists of products, services, recreational media, infrastructure, as well as human resource and literacy. This event was expected that various components of society could participate and play an active role in introducing the development of Islamic economy, including halal industry in Indonesia (Kompas, 17 November 2019).

The emergence of halal industry aims to fulfill the services and products based on the objectives of maquasid shariah. This industry develops not only in Muslim countries but also in non-Muslim countries. The demand for halal products for non-Muslim consumers has increased because they tend to use high-quality, safe and ethical products. It is no longer based on religious obligation or obedience, but halal products have become a market force in the world for both Muslims and non-Muslims (Syarif et al, 2019). According to Elasrag (2016), the large increase in population and purchasing power of Muslim in the world has provided an opportunity for the future of the global halal industry growth. The halal industry sector is able to serve the development of halal lifestyle.

To make halal industry as a major part of the sharia economy in order to develop in Indonesia needs serious effort by many parties and groups. It needs integrated government policy support in the form of investment, production, products and service export, and improvement of human resources. With all this support Indonesia is expected to have the opportunity to become the center for the largest Islamic economy in the world as described in the GIER 2019/2020 report, however, the effort to develop halal industry is 
an attempt to develop the sharia economy in Indonesia, which in turn may have an impact on the realization of prosperity as the main goal. One of efforts to develop halal industry is by exploring issues and challenges related to standard of performance by using maqāsid shariah. The development of performance measurement of maqäsid shariah for businessmen is considered very important, both in the Islamic financial industry and non-financial industries (Rahman et al, 2017).

The government has supported the development of Islamic economy, especially the improvement of halal industry in Indonesia. The government as the policy holder has issued Law Number 33 of 2014 concerning Halal Product Guarantee which is finally known as JPH law. At a practical level, the implementation of the JPH law still has several problems to resolve. This is proven by the results of Indonesia's halal industry ranking, which is satisfying yet (GIEI 2019/2020).

A study on policies related to the guarantee of halal product has been conducted by several researchers like Aziz (2017: 78-94), Lim (2018: 99-107), Salim (2018), Endah (2018: 25-39), Ilyas (2018 : 357-376), Hosana and Nugroho (2018), Sulistiani (2018: 91-97), Kusnadi (2019: 116-132), Istikomah (2019: 18-28), and Nurbaiti (2019). From the studies mentioned above, it is not found research concerning government policy on comprehensive halal product guarantee using maqāsid shariah as the theoretical basis. In addition, previous studies did not focus on the development of halal industry based on the results of the GIEI 2019/2020 ranking.

This study is library research using a qualitative approach. Qualitative research is carried out through the data analysis stage. The data analysis method is using theories and concepts based on the focus of the research, namely the concept of maqäsid shariah, policy and regulation, strategy, and halal industry. With this focus and approach, the study is expected to resolve several issues, especially those related to policies and regulations issued by the government in supporting halal product guarantees and barriers for the implementation of halal certification, and strategies in developing halal industry in Indonesia so that they are able to compete with other countries towards Indonesia as the center for the Islamic economy. 
Ijtihad: Jurnal Wacana Hukum Islam dan Kemanusiaan, Volume 20, No. 1, Juni 2020: 41-60

\section{Policy and regulation of halal product guarantee}

The scope of halal industry in Indonesia covers various aspects, namely cosmetic, food and beverage, medicines, chemical products, genetic engineering products, biological products, and all goods used or utilized by the community (JPH Law article 1). Other broader aspects of halal industry include halal tourism which includes attraction and hospitality. From the all scope of halal industry, there are 6 sectors used as a part in measuring the composite of halal industry, namely food, Islamic finance, tourism, clothe, media and recreation, and pharmaceutical and cosmetic (GIER 2019 / 2020).

This research focuses on describing the regulations related to these 6 sectors. Based on the result of research, the law issued before 2014 regulating clothe, media and recreation, and pharmacy and cosmetic is still very limited. The government had issued Law Number 36 of 2009 regarding health, but it cannot be used as a legal reference for the development of halal pharmaceuticals and cosmetic products. The same case also occurred in the aspects of cloth and media, which have not been supported by adequate regulations. This case shows that until 2014, regulations related to apparel, cosmetic; media and recreation, and halal pharmaceuticals were very inadequate.

In the field of tourism, although halal tourism market share is being developed in Indonesia, it must be understood that up to now there has not been standard of halal concept setting for tourist destinations such as restaurant, hotel, sauna, spa, travel agent, airlines, and others (Destiana, 2019 ). Halal tourism arrangement is found in the instructions of DSN MUI Number 08/DSN/MUI/2016 concerning Guidelines for Organizing Tourism based on Sharia principles. This instruction legally does not have binding power. Although the government subsequently issued a legal product, Law Number 10, 2009 concerning tourism and supported with the Presidential Regulation Number 70, 2019 on tourism and creative economy, it cannot be considered as legal standing for the development of halal tourism in Indonesia. It needs a more comprehensive rule that regulates halal tourism so that it can provide strength and legal rule to the tourism industry and agency in the regions as an effort to develop halal tourism (www.republika.co.id, 8 March 2019).

Regulation related to sharia finance in Indonesia is considered quite encouraging. Regulation in this field is massive and rigid enough to answer the challenges and problems 
in the implementation and technical operations of the Islamic financial institution in Indonesia. In 2008, the government issued Law No. 21, 2008 concerning banking. It experienced a very good development when plan, regulation and supervision of Islamic financial institutions are no longer at Bank Indonesia (BI), but are run by the Islamic Financial Services Authority (OJK). In 2013, FSA moved quickly by issuing at least 214 regulations, consisting of 117 regulations on Islamic banking, 23 regulations on the nonIslamic financial industry, and 74 regulations on capital markets and Islamic capital markets. This condition was strengthened by instructions issued by the National Sharia Council (DSN) MUI quite massively. DSN MUI has issued 109 instructions on Islamic financial institutions (Ulum, 2017).

In sector of food and beverage, since the New Order government until the reform era some regulations have been issued in the form of laws. During the New Order era, a Joint Decree (SKB) was issued by Minister of Health of RI and Minister of religious affairs of RI Number 427/Menkes/SKB/VIII/1985, Number 68, 1985 regarding the inclusion of "halal" writing on a food label. Shortly after that, the Decree of Indonesian Ulema Council (MUI) Number: Kep/18/MUI/I/1989 was issued to examine halal products which are then called as halal certification. To carry out this task, then it was formed LPPOM MUI in collaboration with Bogor Agricultural Institute (IPB) in the form of laboratory and its staff to conduct product inspection. The process of getting halal certification is intended to obtain halal product guarantee. Subsequently, in 1991 there was a Presidential Instruction No. 2, 1991 to increase the development and supervision of production and distribution of processed food.

Five years later, Law No. 7, 1996 concerning food was issued. This law aimed to help protect Muslims from illicit products. This law was followed up with cooperation between the Ministry of Health, the Ministry of Religious Affairs, and the Indonesian Ulema Council on the implementation of halal label on food in 1996. Shortly after that, the decree of Minister of Health RI Number: 82/MENKES/SK/1996 regarding the inclusion of "halal" on food label was issued, then the rules were changed by the decree of the Minister of Health RI Number: 924/MENKES/SK/VIII/1996 concerning changes to the Decree of the Minister of Health Number: 82/MENKES/SK/I/1996. Furthermore, 
Ijtihad: Jurnal Wacana Hukum Islam dan Kemanusiaan, Volume 20, No. 1, Juni 2020: 41-60

at the beginning of the reform era, Law Number 8, 1999 concerning consumer protection was issued, which included the principle of justice, benefit, balance, security and consumer safety, and the principle of legal certainty. The importance of product selection and certification from local and foreign the country, the Decree of the Minister religious affairs RI Number 519 of 2001 concerning halal food inspection institutions was issued.

To strengthen the supervision of halal food, Law Number 7, 1996 was changed by Law Number 18, 2012 concerning food. Article 95 states that both central and regional governments supervised the implementation of halal product guarantee systems for food. The rule explicitly stated that food supply that is not contrary to religion and belief was the responsibility of the central and regional government. Food safety is important to maintain the quality of food, and it is not contrary to religion, beliefs and culture of the community. On the other hand, food safety is intended to prevent the possibility of pollution caused by biological and chemical substances or other objects that can endanger human health. Regarding the food security related to food halal, it is stated that this is the responsibility of central and regional governments to supervise the implementation of halal product guarantee system which is implemented in accordance with regulations and statutory provisions.

The elaboration and explanation above can be understood that in the domain of positive law, there are lots of legal products in the form of legislation that can become a legal basis for consumer protection through the consumption of halal products. Consumption of halal products is not limited to food and beverage, yet it includes various aspects such as clothe, travel, finance, cosmetics, and medicines. In producing halal products, the input of raw materials, processing technology, and packaging must reflect the cleanliness and maintain their halal status so that the product can be accepted by consumers (Annisa, 2019). It indicates the importance of protecting consumers from various aspects. However, government support in the sector of cloth, pharmacy, halal tourism, and halal cosmetics, as well as halal media and recreation, which is realized in the form of legislation, is very limited and inadequate. This is different from the legislation related to halal product standards in Indonesia in the field of halal food and Islamic finance. Regulation that supports both aspects are very massive, and its progress is very convincing, even though the regulations 
issued are still partial, inconsistent, not systemic, and overlapping, so they do not provide legal certainty and guarantee.

The regulation, which is more comprehensive and covering all aspects and providing legal certainty in an effort to protect consumers in accordance with the provisions of Islamic law is written in JPH Law. The JPH Law covers various regulations in all existing regulations. JPH Law also covers all regulation of halal product guarantees which previously did not exist at all. The JPH Law is a part of a legal system which had substantial legal strength and certainty, which is imperative (Putra, 2017). As past of JPH Law, the government issued Regulation No. 33, 2014 concerning halal product guarantees, namely Governmental Regulation (PP) No. 31, 2019. This rule has regulated every product that enters, circulates, and is traded in Indonesia is required to have a halal certificate, except for products whose raw materials are haram.

The implementation of halal product guarantee system is an effort conducted by the government to protect Muslims in performing their religious teachings. Besides, it is also to protect consumer rights through legal certainty of halal products, which are implemented in halal certification for standards products. To produce halal products, it needs a process that can guarantee the halal status of a product. The process of implementing halal labelling and certification refers to JPH Law which covers aspects of legal certainty, justice, protection, effectiveness and efficiency, accountability and transparency as well as professionalism. As stated in JPH Law Article 3, the purpose of guaranteeing halal products is to (1) provide security, safety, comfort, and certainty of the availability of halal products for Muslim consumers who consume and use products; and (2) increase added value for businesses to produce and sell halal products.

The issuance of JPH and PP Law is one of the government's efforts to take part in the development of the global halal industry. Although it is known that its influence on growth and acceleration of halal industry cannot be felt significantly, the issuance of JPH Law as a legal regulation for halal products in Indonesia can be used as a basis for guaranteeing halal products. In practice, JPH Law still faces challenges as well as obstacles because they must be supported by other regulations. On the other hand, the provisions in the PP governing all products must be halal certified with the guarantee that there are no illicit raw materials 
Ijtihad: Jurnal Wacana Hukum Islam dan Kemanusiaan, Volume 20, No. 1, Juni 2020: 41-60

for halal-certified products which will be a challenge for the Halal Product Guarantee Agency (BPJPH).

\section{Challenges for halal certification after the issuance of JPH law}

The implementation of halal product guarantees and halal certification in Indonesia had been carried out for over 30 years by MUI through LPPOM. The authority for halal certification was officially transferred to BPJPH since 17 October 2019. BPJPH is an institution that has the authority and responsibility to oversee halal products and accelerate the implementation of JPH Law for consumer protection and the development of halal industry in Indonesia. According to JPH Law article 6, BPJPH has the authority to hold halal product guarantees that includes: (a) formulating and establishing halal product guarantee policies; (b) establishing the norms, standards, procedures and criteria for the guarantee of halal products; (c) issuing and revoking halal certificates and halal labels on products; (d) registering halal certificates on foreign products; (e) socializing, educating and publishing halal products; (f) accrediting halal guarantee institutions; (g) registering halal auditor; (h) supervising halal product guarantees; (i) providing guidance for halal auditors; and (j) cooperating with domestic and foreign institutions in the field of halal product guarantees.

The JPH Law requires all products that enter, circulate and trade in the territory of Indonesia to have a halal certificate. The existence of halal certificate is intended so that consumers who need halal products have a guarantee. The JPH Law does not solely provide consumer protection and guarantee by providing halal certification. Producers benefit from JPH Law, which is the legal certainty of goods produced, so this law has a positive impact on the business world (Charity, 2017). Since the issuance of JPH Law, the trend of public interest in halal products and halal labels increases significantly. This trend is in line with the increase in halal aspects in various forms of implementation in society such as in institutional aspect, law, certification, promotion and development of various halal products (Nurbaiti, 2019). JPH Law also regulates that all legal material content must be upheld accordingly on October 17, 2019. This date is the deadline for implementing halal product guarantees in the form of halal certification. According to the results of 
research conducted by Takhim (2019), the implementation of JPH Law starting from 2019 is a benefit for Muslim consumers and the general community, because it can guarantee the safety and halal of a product.

The implementation of JPH Law is not applied optimally because there are still many challenges and obstacles faced. For producers, the implementation of JPH Law is a challenge in preparing halal certification for their products. JPH Law seems burdensome and difficult because of complicated requirements high cost. The cost of halal certification is considered as a burden for some businessmen, and they feel reluctant to get halal certification. According to Ramlah (2018), the reluctance to get halal certification has an impact on the occurrence of food products that do not have a halal label on their package. This is a basis for obstacles in guaranteeing Muslim consumers by the government, although it has issued various regulations.

According to Kusnadi (2019), JPH Law as a legal system will not run effectively as long as the problem such as the structure and legal substance of legal system of halal product guarantee has not been resolved. Based on the theory of function efficacy of the legal system of Lawrence M. Friedman, Kusnadi concluded that the structure of JPH Law is not ready to undertake the halal process system. The substance of JPH Law seems burdensome and incomplete as long as there are no supporting regulations that have been legalized. This is an obstacle as well as a challenge for the implementation of JPH Law.

To implement JPH Law properly, the legal substance must be improved by issuing a number of derivative regulations. It at least needs 8 Government Regulations (PP) to support the implementation of JPH Law, especially to carry out the mandate in articles 11, 16, 21 (paragraph 3), 44 (paragraph 3), 46 (paragraph 3), 47 (paragraph 4 ), 52 and 67 (paragraph 3). The intended articles and paragraphs are related to: (1) cooperation between BPJPH and the Ministry, LPH and MUI, (2) Halal Inspection Institution (LPH), (3) location, place and Halal Product Process (PPH) tool, (4) halal certification costs, (5) JPH international cooperation, (6) procedures for registration of overseas halal products, (7) JPH supervision, and (8) gradual types of halal-certified products. In addition to optimizing the implementation of JPH Law, it needs at least 11 Ministerial Regulations (Permen), mainly related to articles 22 (2), 27 (3), 28 (4), 29 (3), 30 (3) , 40, 41 (2), 42, 45 
ljtihad: Jurnal Wacana Hukum Islam dan Kemanusiaan, Volume 20, No. 1, Juni 2020: 41-60

(2), 48 (2), and 55. The mandate of JPH Law as in articles and paragraphs above is related to: (1) the procedure for imposing administrative sanctions on businessmen who does not separate location, place and PPH tools, (2) procedures for imposing administrative sanctions for those who produce goods from illicit material, but they do not include nonhalal information on the package, (3) halal supervisors, (4) procedures for submitting halal certificate applications, (5) procedures for establishing Halal Inspectorate Institutions, (6) halal labels, (7) procedures for imposing administrative sanctions for businessmen who include halal labels not in accordance with the provisions, (8) renewal of halal certificates, (9) BPJPH financial management, (10) procedures for imposing administrative sanctions for businessmen who do not register; and (11) procedures for community participation and award.

To complete issuing derivative rules is not easy because it covers different sector. It requires the involvement of various sectors within the government. The complexity of the formulation of derivative regulations on JPH Law will be an obstacle if the derivative rules are not issued soon. This condition is a challenge for the government to meet the expectations and aspirations of Indonesian people who are predominantly Muslim by speeding up the derivative regulations needed so that JPH Law can be implemented effectively throughout Indonesia. The implementation of JPH Law is not running optimally as long as there is no support from government or ministry regulation.

Based on the consideration of various stakeholders, including for the interests of the business world, the halal-certified obligation is implemented in stages, even though the actual implementation is mandatory. Certification requirements are also not applied to all products on the market, so producers are ready and have more time to prepare halal certification for their products. Therefore, giving time to businessmen to prepare themselves to get halal certification more massively is the right government policy.

\section{The up and down of halal industry ranking}

Based on the ranking of Global Islamic Economy Index (GIEI), Indonesia has a tendency to stagnate in the $10^{\text {th }}$ position from 2014 to 2018. Even in 2017, the Indonesian GIEI rank dropped to $11^{\text {th }}$ or down one rank. An encouraging development occurred in 2019. 
According to GIER 2019/2020 report, Indonesia's score had reached 49 and ranked $5^{\text {th }}$. It means that in 2019 there has been an upward trend in rankings compared to previous years. This condition is greatly influenced by the composite assessment of halal industry in the halal clothing sector, according to the GIER 2019/2020 report, Indonesia ranked $3^{\text {rd }}$, which was previously ranked $2^{\text {nd }}$ in 2018. Despite a downgrade from the previous year, this industry has never been in the top 10 from 2014 to 2017. This shows a very significant ranking increase in the halal clothing sector in 2018 and 2019.

On the other hand, there was a significant increase in ranking especially in the halal tourism sector, which ranked $4^{\text {th }}$ in 2017 and 2018. The same thing happened in 2019 based on GIER 2019/2020 report. Over the past 3 years, Indonesia has experienced a very good increase in this sector compared to the previous 3 years, which have not been able to penetrate the top 10. The Indonesian Ministry of Tourism announced that Indonesia was designated as the world's best halal tourism destination in 2019 according to the standard of Global Muslim Travel Index (GMTI) 2019, surpassing 130 tourist destinations all over the world (www.kemenpar.go.id, 9 April 2019).

The ranking in sharia financial sector is up and down. GIER 2019/2020 reported that in this sector, Indonesia ranked $5^{\text {th }}$ after Malaysia, Bahrain, UAE and Saudi Arabia. The report of Islamic Finance Development Report (IFDI) 2019 stated that Indonesia ranked 4th, under Malaysia, Bahrain and the United Arab Emirates. Meanwhile, according to the Global Islamic Finance Report (GIFR) 2019 from the Cambridge Institute of Islamic Finance (IIF), Indonesia is the top-ranking country with a score of 81.93. Indonesia has displaced Malaysia, which has dominated this rank since 2011 (Kompas 22 November 2019). This ranking achievement cannot be separated from the support of National Sharia Finance Committee (NSFC) which had been formed since 2016 as a forum for coordination, synchronization and synergy in the direction of national development policies and strategic programs in the Islamic financial sector.

The increase in this sector was not in line with the developments of pharmaceutical and halal cosmetics sector that dropped to top 10 in 2018 and 2019 after the previous four years were ranked $7^{\text {th }}$ and $8^{\text {th }}$. The same thing happened to the media and recreation sectors which were not included in the top 10 largest countries. Even the score decreased in 2018. 
Ijtihad: Jurnal Wacana Hukum Islam dan Kemanusiaan, Volume 20, No. 1, Juni 2020: 41-60

The two sectors that never reached the top 10, one sector in a stagnant position, while the other with a declining rank. This has become a major factor causing Indonesia to not be able to penetrate better rank than 10 in 2018, although 2 (two) other sectors have increased.

\section{The values of maqāṣid shariah in JPH law}

Maqashid syariah is a terminology that consists of two words, namely maqashid and syariah (Hans, 1980: 767, and Munawir: 1125). Maqashid syariah can be interpreted as the aims of Islamic teachings or the objectives of the maker of sharia in outlining Islamic teachings. Al-Ghazali and ash-Syatibi argue that the essence of maqashid syariah is the goodness for humankind. The existence of maqāșid shariah aims to create goodness for all people.

One of the efforts to maintain maslahah daruriyyat, especially in the aspect of religion and soul, is manifested in the guarantee and protection of halal products consumed by Muslim consumers. People's need for halal products in accordance with the Islamic law is not only food and beverage products, but also other products such as cosmetics, medicines, chemical products, biological products, genetic engineering products, and products used by Muslims. The obligation of halal certification can increase consumer's confidence in the quality of a product. This obligation is an effort to meet the needs of the community for halal products. Etymologically the "halal" word is derived from the word hill which means "free". In other words, halal is something that is permissible and can be done because it is free of the regulation (Ma'luf, 1986).

The consumption of halal and good product is a manifestation of the implementation of religious teachings. To fulfill the needs is still permissible as long as it is able to bring goodness. Consumption of halal and good products is actually directed to bring the good. Fulfilling these needs is an important thing in human life that will have an impact on the safety and comfort of using products in circulation. Therefore, the presence of BPJPH answers the fulfillment of consumers' needs in guaranteeing halal products that are included in the category of maslahah darürriyat because they are closely related to the basic needs of people.

Government policy through legal products is to protect consumer rights. In formulating policies, regulations made by the government should reflect the values of maqăsid, especially encouraging the preservation of religion and spirit. With maqassid shariah regulations and 
policies are expected to encourage halal lifestyle and support the development of halal industry. Sulistiani's study (2018: 91-97) concluded that in the framework of maqassid shariah, the development of halal industry will be in line with the objectives of the shariah law. Therefore the consumers and Muslim community are protected to meet their needs through halal industry which is dynamic and innovative.

According to Aziz (2017), the goals stated in JPH Law are important components that must be achieved in human life. In the context of providing halal product guarantees, which is built from five important pillars in human life is a form of implementing the principle of protecting the soul. According to Ilyas (2018), certification and labeling of halal products are an effort to provide protection to Muslims in fulfilling the needs and providing legal certainty of halal of a product so that it can be categorized as maslahah darimiyyat. The values of maslahah contained in halal certification and labeling include 4 (four) things, namely protection of Muslims in carrying out their teachings, providing a sense of justice, health, and legal certainty as citizens.

Based on the elaboration above, maqäsidvalues reflected in JPH Law include several things. First, the existence of religious protection from the state and by individual by implementing the provisions of JPH Law, both as consumers and producers. This is indicated by the guarantee of state protection for all followers of religion to worship and practice their religious teachings. Second, the existence of protection of soul and reason so that every individual does not consume illicit products. This is demonstrated by the protection of consumers' rights to get halal products through a long process to ensure that the product is safe. It includes the supply of materials, processing, storage, packaging, distribution, sale, and serving of the product. Third, the existence of protection and legal certainty toward halal product. This is indicated by the existence of halal certificate, administrative and criminal sanctions for producers who break the rule stated in JPH Law. In this context, JPH Law is seen as a regulation that has met the standards expected to give benefit to people. Meeting the needs of halal products will have an impact called maslahah. Mașlahah is not the ultimate goal of human life; it is only a way to reach prosperity. Prosperity is the ultimate goal of every human activity whose outcomes must be achieved through maslahah (P3EI UII and Bank Indonesia, 2012). 
Ijtihad: Jurnal Wacana Hukum Islam dan Kemanusiaan, Volume 20, No. 1, Juni 2020: 41-60

\section{Developmental strategy of halal industry}

The strategy for the development of halal industry in Indonesia is done through various

efforts. In terms of developing halal industry in Indonesia, there is good integration among government, community, halal industry sectors and related stakeholders. With synergy, it is expected that halal product guarantee regulation system will gradually become better than before. In addition, the development of halal industry should be supported synergistically by other sectors.

Sungkawaningrum' study et al. (2019) shows that Islamic banking has a significant role for the development of halal industry in Indonesia. The cooperation between the halal industry and sharia banking through the use of shariah banking products, the food, medicine, cosmetics, fashion, and tourism industries, will be able to grow and develop the product based on syariah guidance. This is in line with the results of Rahmayati's research (2018), which states that Islamic banking can encourage the improvement and development of halal industry sector through financing customers at Islamic banks. Thus the Indonesian economy will increasingly develop along with the growth of Islamic banking.

On the other hand, halal industry development strategy has been carried out by the government, one of which is through the policy of strengthening regulations in the form of halal certification obligation. Strengthening regulations in the form of halal certification obligation is real support from the government to develop halal industry in Indonesia. Mufidah's study (2017) states that the historical development of JPH Law in Indonesia explains the process of the Indonesian government in carrying out the functions of protecting and guiding the community with the aim of providing legal protection. It was started from the overlapping JPH regulatory system, which is not consistent and ambiguous. This development indicates a positive change in the history of JPH Law in Indonesia. With the existence of JPH Law as well as its implementing regulations and supported by a roadmap that has been prepared before is expected to be able to move the Indonesian economy by making Indonesia as the center for the world's halal products (Istikomah, 2019).

Besides, the government has also prepared a road map for the development of halal industry in the form of halal economy and strategy roadmap. It includes the strategies for 
developing reliable sectors, legal aspects, research, standardization, and infrastructure that could encourage the development of halal industry. This roadmap serves as a guide as well as a guideline for the government, halal industry players, and stakeholders as an effort to be actively involved in developing halal product industry and shariah economy.

\section{Indonesia as the center for islamic economics}

The phenomenon of global economic development shows that the Islamic economy has now become a source of economic growth in various countries in the world, both in Muslim and non-Muslim countries. Economic growth is one of the goals of the Islamic economy in achieving ultimate prosperity. Halal industry is part of the Islamic economy, so the development of halal sector will have a major impact on the Islamic economy. Islamic economics must contribute to pushing Indonesia to become the world's leading Islamic economic center.

The vision mentioned above is now increasingly open and prospective. Randeree's (2019) claims that it experienced the development of Muslim population and improving the socioeconomic status of Muslims in developed and developing countries. The increasing demand for shariah and halal products will have a positive impact on Islamic economic growth. To realize the vision of Indonesia, it needs synergy and hard work as well as the support from all parties, including the government, community, halal industry players and stakeholders, especially in developing halal products and industries. Indonesia has the largest Muslim population in the world, so it has the potential to become a halal industry market share. The large Muslim population will indirectly increase the domestic demand for halal products in Indonesia and be followed by international market demand. By developing halal products, it is not impossible that Indonesia will become the center for halal industry. Somehow, the halal industry is a new source of economic growth that will lead Indonesia to become the center for the Islamic world economy, so this potential needs to be optimized.

To realize this vision, there must be stages of the strategy of implementation. The strategy is outlined in the quick wins, namely milestone of sharia economic development in Indonesia through 6 stages, as mentioned in the Indonesian Sharia Economic Master 
Ijtihad: Jurnal Wacana Hukum Islam dan Kemanusiaan, Volume 20, No. 1, Juni 2020: 41-60

Plan 2019-2024 (2018: 422-423). First, laying the foundation for strengthening the legal aspects and coordination carried out in 2019. Second, conducting a national campaign on halal lifestyle to strengthen literacy and awareness for the consumption of Muslimfriendly commodities in 2020. Third, encouraging the formation of a national halal fund that was carried out massively in 2021. Fourth, establishing halal industry to strengthen the domestic halal industry in 2022. Fifth, establishing and activating the Islamic Inclusive Financial Services Board (IIFSB) so that Indonesia may become an international reference center and standard technical notes for global implementation in 2023. Sixth, strengthening international economic cooperation through the International Halal Center in 2024.

\section{Conclusion}

Based on the research findings, it can be concluded that to guarantee halal products in a systematic and comprehensive way for Indonesian society. The government has issued JPH Law which contains the values of maqạsid shariah in it. The values of maqāsid shariah contained in JPH Law include 3 things. First, there was a protection of religion from the state and individual. Second, there was a protection of the soul and reason so that every individual does not consume illicit products. Third, there was a legal protection and certainty about halal status of a product.

Besides, it was also found that there were difficulties in the process of obtaining halal certification faced by the producers. First, the issuance of derivative rules was indeed not easy because it was cross-sectorial, and it required the involvement of various sectors in the government which then became an obstacle in the process of halal certification. Second, the human resources to implement the halal certification program for all national businessmen were a heavy burden for BPJPH. Third, important components such as auditors, halal guarantor institutions, and other technical rules had not been fully met as expected. Fourth, the regulations supporting the implementation of JPH Law were still limited. Based on these research findings, the government and related ministries need to immediately compile and issue regulations that support halal certification so that these efforts will encourage the development of halal industry, which later can realize Indonesia as a trendsetter of the Islamic world economy. 
The developmental policy of halal product guarantee...(Agus Waluyo)

\section{Bibliography}

Afriqi, Ibn Mansur al-, Lisan al-'Arab, juz VIII,(Beirut: Daras-Sadr, t.th..

Al-Ghazali, Abu Hamid, Al-Mustashfa, bi Tahqiqi Abdullah Mahmud Muhammad Umar, Cet. ke-1, Beirut: Dār al-Kutub al-Ilmiyyah, 2008.

, Al-Mustasfa min al-'Ilmi al-Ușül, tahqiq wa ta'liq Muhammad Sulaiman al-Asyqar, juz.

1, Beirut: Mu'assasat al-Risalah, 1997.

Annisa, Arna Asna, “Kopontren dan Ekosistem Halal Value Chain”, dalam Jurnal Ilmiah Ekonomi Islam, Vol. 5 No. 1, 2019, hlm. 1-8 .

Aziz, Muhammad, "Perspektif Maqāṣid Al-Sharīah dalam Penyelenggaraan Jaminan Produk Halal di Indonesia Pasca Berlakunya Undang-Undang nomor 33 Tahun 2014

Tentang Jaminan Produk Halal”, dalam AL HIKMAH Jurnal Studi Keislaman, Vol. 7, No. 2, 2017, hlm. 78-94.

Charity, May Lim, "Jaminan Produk Halal Di Indonesia”, dalam Jurnal Legislasi Indonesia, Vol. 14 N0. 01 (2017), hlm. 99-108.

Darojatun, Rina, “Tren Produk Halal, Gaya Hidup Syar'i dan Kesalehan Simbolik: Studi Tentang Muslim Kelas Menengah”, dalam Wardah, Vo. 19, No. 2, 2018, hlm. 135-157. Destiana, Riska dan Retno Sunu Astuti, "Pengembangan Pariwisata Halal di Indonesia", dalam Prosseding Collaborative Governance dalam Pengembangan Pariwisata di Indonesia, Volume 01, Nomor 01, Tahun 2019, hlm. 331-353.

Elasrag, Hussein, "Halal Industry: Key Challenges and Opportunities" dalam Munich Personal RePEc Archieve, February 20, 2016.

Fauzia, Ika Yunia dan Abdul Kadir Riyadi, Prinsip Dasar Ekonomi Islam Perspektif Maqashid Syariah, Jakarta: Kencana Prenadamedia Group, 2014.

Gillani, S. H., Ijaz, F., \& Khan, M. M., "Role of Islamic Financial Institutions in Promotion of Pakistan Halal Food Industry", in Islamic Banking and Finance Review, Vol. 3, No. 1, 2016, p. 29-49.

Ilyas, Musyfikah, "Sertifikasi dan Labelisasi Produk Halal Perspektif Maslahat", dalam AlQadāu, Vol. 4, No. 2 Desember 2017, hlm. 357-376.

Istikomah, "Peluang dan Tantangan Implementasi UU JPH (Studi Analisis atas UU No. 33 tentang Jaminan Produk Halal)", dalam At-Tasharruf; Jurnal Kajian Ekonomi dan Bisnis 
ljtihad: Jurnal Wacana Hukum Islam dan Kemanusiaan, Volume 20, No. 1, Juni 2020: 41-60

Syariah, Vol. 1 No.1. April 2019, hlm. 18-28.

Auda, Jasser, Maqäsid asy-Syariah as Philosophy of Islamic Law: A Systems Approach, London: IIIT, 2008.

Khan, M. Fahim, "Theory of Consumer Behavior in an Islamic Perspective", dalam Sayyid Tahir et.al. (eds.), Readings in Microeconomics: An Islamic Perspective, Malaysia: Longmann Malaysia, 1992.

Kementerian Perencanaan Pembangunan Nasional/Badan Perencanaan Pembangunan Nasional, Masterplan Ekonomi Syariah Indonesia 2019-2024 Hasil Kajian Analisis Ekonomi Syariah di Indonesia, Cet. I, 2018.

Keputusan Menteri Agama (KMA) Nomor 982 Tahun 2019 tentang Layanan Sertifikasi Halal.

Kusnadi, Moh., "Problematika Penerapan Undang-Undang Jaminan Produk Halal Di Indonesia", dalam Islamika : Jurnal Keislamandan Ilmu Pendidikan, Vol. 1, No. 2, Juli 2019, hlm.116-132

Mas'ud, Muhammad Khalid, Islamic Legal Philosophy, Islamabad: Islamic Research Institute, 1977.

Mufidah, Ana, "Kewenangan Kementerian Agama dan MUI dalam Sertifikasi Halal Berdasarkan Undang-undang RI Nomor 33 Tahun 2014 tentang Jaminan Produk Halal, Masters Thesis, Universitas Islam Negeri Maulana Malik Ibrahim, 2017.

Mujiono, Slamet, "Perlindungan Konsumen :Regulasi Bisnis" dalam JEBI Jurnal Ekonomi dan Bisnis Islam)-Volume 1, No.1, Januari-Juni 2016, hlm. 67-81.

Munawir, Ahmad Warson, Kamus al-Munawnir Arab-Indonesia, Surabaya: Pustaka Progresif, 1997.

Noordin, Nurulhuda, Noor, N. L., and Samicho, Z. "Strategic Approach to Halal Certification System: An Ecosystem Perspective", in Procedia-Social and Behavioral Sciences, 121 (2014), p. 79 - 95.

Nurbaiti, "Perkembangan Minat Masyarakat pada Produk Halal dan Label Halal di Indonesia: Google Trends Analysis", dalam Prosseding Seminar Nasional Cendekiawan ke-5 Tahun 2019 Buku I.

P3EI UII dan Bank Indonesia, Ekonomi Islam, Jakarta: Rajawali Press, 2012. 
Peraturan Pemerintah Nomor 31 Tahun 2019 tentang Peraturan Pelaksanaan UndangUndang Nomor 33 Tahun 2014 Tentang Jaminan Produk Halal.

Putra, Panji Adam Agus, "Kedudukan Sertifikasi Halal dalam Sistem Hukum Nasional Sebagai Upaya Perlindungan Konsumen dalam Hukum Islam”, dalam Amwaluna: Jurnal Ekonomi dan Keuangan Syariah, Vol.1 No. 1 Januari 2017, hl. 149-165.

Rahman, F., Tareq, M., Yunanda, R. and Mahdzir, A. (2017), "Maqashid Al-Shari'ah-based performance measurement for the halal industry", in Humanomics, Vol. 33 No. 3, pp. 357-370.

Rahmayati, "Strategi Perbankan Syariah sebagai Solusi Pengembangan Halal Industry di Indonesia", dalam AT-TAWASSUTH: Jurnal Ekonomi Islam, Vol. III,| No. 2, 2018, hlm. 313-334.

Ramlah, Ulya Fuhaidah, "Implementasi Jaminan Produk Pangan Halal di Jambi" dalam Ijtihad: Jurnal Wacana Hukum Islam dan Kemanusiaan, Vol. 18, No. 2, 2018, hlm. 211-226.

Randeree, Kasim, "Demography, Demand and Devotion: Driving the Islamic Economy", in Journal of Islamic Marketing, Vol. 11 No. 2, 2019, pp. 301-319.

State of the Global Islamic Economic Report 2019/2020.

Sulistiani, Siska Lis, Analisis Maqāṣid Syariah dalam Pengembangan Hukum Industri Halal di Indonesia, Jurnal Law and Justice, Vol. 3 No. 2, 2018, hlm. 91-97.

Sungkawaningrum, Fatmawati, dan Amin Nasrullah, "Eksplorasi Peran Perbankan Syariah dalam Memajukan Industri Halal di Sektor Makanan Halal" dalam Wahana Islamika: Jurnal Studi Keislaman, Vol. 5, No. 2 Oktober 2019, hlm. 32-48.

Syarif, Fazlur dan Naif Adam, "Pertumbuhan dan Keberlanjutan Konsep Halal Economy di Era Moderasi Beragama” dalam Jurnal Bimas Islam, Vol. 12 No. 1, 2019, hlm. 93122.

asy-Shātibi, al-Muwāfaqāt fì Usūl asy-Shariah, Beirut: Dār al-Kutub al-Ilmiyyah, t.th..

Takhim, Muhammad, 'Problema Sertifikasi Halal Pasca Pemberlakuan UU No. 33 Tahun 2014 tentang Jaminan Produk Halal”, dalam INVEST AMA: Jurnal Ekonomi Bisnis dan Sosial, Vol. 3, No.1, 2019.

Ubaidi, Hamadi al-, Ibn Rusyd wa 'Ulūm asy-Syarìah al-Islāmiyyah, Beirut: Dār al Arabiy, 1991. 
ljtihad: Jurnal Wacana Hukum Islam dan Kemanusiaan, Volume 20, No. 1, Juni 2020: 41-60

Ulum, Fahrur, "Progresifitas Regulasi Keuangan Syariah di Indonesia", dalam Al-Daulah: Jurnal Hukum Dan Perundangan Islam, Vol. 7, No. 2, Oktober 2017, hlm. 419-443.

Undang-Undang Republik Indonesia Nomor 18 Tahun 2012 tentang Pangan.

Undang-Undang Republik Indonesia Nomor 33 Tahun 2014 tentang Jaminan Produk Halal.

Wehr, Hans, A Dictionary of Modern Written Arabic, London: McDonald \& Evan Ltd., 1980. 